\title{
GROWTH AND PROTEIN CONTENT OF Ulva prolifera MAINTAINED AT DIFFERENT FLOW RATES IN INTEGRATED AQUACULTURE SYSTEM
}

\section{PERTUMBUHAN DAN KANDUNGAN PROTEIN Ulva prolifera YANG DIPELIHARA DENGAN LAJU ALIRAN BERBEDA PADA SISTEM BUDIDAYA TERPADU}

\author{
Wastu Ayu Diamahesa ${ }^{1}$, Toshiro Masumoto ${ }^{2}$, Dedi Jusadi ${ }^{*}$, and Mia Setiawati ${ }^{1}$ \\ ${ }^{1}$ Department of Aquaculture, Faculty of Fisheries and Marine Science, IPB 16680, Indonesia \\ ${ }^{2}$ Laboratory of Fish Nutrition, Faculty of Agriculture, Kochi University, 783-8502, Japan \\ *E-mail: dedidj@ipb.ac.id; siflounder@gmail.com
}

\begin{abstract}
Efforts to reduce the impact of waste improvement on degradation of water quality can be transferred by utilization of inorganic waste as a source of seaweed nutrition. This study aimed to determine the growth and protein content of Ulva prolifera maintained at different flow rates in integrated aquaculture system. 9 Yellowtail stocked with $5.095 \mathrm{~g}$ with an average weight of $566.11 \pm 81.51 \mathrm{~g}$ were kept in 540 $\mathrm{L}$ tank for 24 days, by water flowing at the rate of $10 \mathrm{~L} \mathrm{~min}^{-1}$. Water from the fish tank was distributed into the sediment tank and go to 6 Ulva tanks with the flow rate of $0.5,1.0$ and $1.5 \mathrm{~L} \mathrm{~min}^{-1}$. Test parameters measured were growth performance of Yellowtail, biomass of Ulva prolifera, protein content of Ulva prolifera, and total ammonia nitrogen. The measurement results showed that the biomass of fish increased to $5.408 \mathrm{~g}$, then biomass of Ulva increased to $42 \mathrm{~g}, 156 \mathrm{~g}$ and $155 \mathrm{~g}$ for flow rate of 0.5 $\mathrm{L}, 1 \mathrm{~L}$ and $1.5 \mathrm{~L} \mathrm{~min}^{-1}$, respectively. The protein content of Ulva for all the treatments was the same $(\mathrm{P}>$ $0.05)$. A total of ammonia in the tank outlet of Ulva (0.0202 - $0.1137 \mathrm{mg} \mathrm{N} \mathrm{L-1})$ were smaller than those were in the inlet $(0.0286-0.1394 \mathrm{mg} \mathrm{N} \mathrm{L}-1)$.
\end{abstract}

Keywords: growth, integrated aquaculture system, protein, Ulva prolifera

\begin{abstract}
ABSTRAK
Upaya mereduksi dampak peningkatan limbah terhadap penurunan kualitas air dapat dialihkan dengan cara memanfaatkan limbah anoganik sebagai sumber nutrisi rumput laut. Penelitian ini bertujuan untuk menentukan tingkat pertumbuhan dan kandungan protein Ulva prolifera yang dipelihara dengan debit air yang berbeda pada sistem budidaya terpadu. Ikan Yellowtail sebanyak 9 ekor dengan biomassa 5,095 g dan berat rata-rata 566,11 $\pm 81,51 \mathrm{~g}$ dipelihara dalam tangki kapasitas $540 \mathrm{~L}$ selama 24 hari, dan diberi air mengalir dengan debit $10 \mathrm{~L} \mathrm{~min}^{-1}$. Air dari tangki budidaya ikan didistribusikan ke dalam tangki sedimentasi kemudian dialirkan ke dalam 6 tangki pemeliharaan Ulva pada debit 0,5, 1,0 dan 1,5 $\mathrm{L} \mathrm{min}^{-1}$, masing-masing 2 ulangan. Parameter uji yang diukur adalah kinerja pertumbuhan ikan Yellowtail, biomass Ulva prolifera, kandungan protein Ulva prolifera, dan total ammonia nitrogen. Hasil pengukuran menunjukakan bahwa biomass ikan meningkat menjadi 5,408 g, sedangkan biomassa Ulva meningkat menjadi $42 \mathrm{~g}, 156 \mathrm{~g}$ dan $155 \mathrm{~g}$ untuk masing-masing laju aliran 0,5 L, 1,0 L dan 1,5 L $\mathrm{min}^{-1}$. Kadar protein dari Ulva di semua perlakuan sama $(P>0,05)$. Total ammonia pada tangki outlet $\left(0,0202-0,1137 \mathrm{mg} \mathrm{N} \mathrm{L}^{-1}\right)$ Ulva lebih kecil dari inletnya $\left(0,0286-0,1394 \mathrm{mg} \mathrm{N}^{-1}\right)$.
\end{abstract}

Kata kunci: pertumbuhan, sistem budidaya terpadu, protein, Ulva prolifera

\section{INTRODUCTION}

A rapid development of aquaculture industry in coastal areas throughout the world has been accompanied by an increase in environmental impacts (Diana et al., 2013). Moreover, In Japan, yellowtail Seriola quinqueradiata was the most economically important fish. The production per year was around 150,028 ton in 2004 (Nakada, 2008).

During cultivation process, feed is the main source of potentially contaminating waste discharge, because only a small portion $(25 \%)$ is used for growth, $25 \%$ is used for 
metabolism and the remaining is excreted into various organic and inorganic compounds such as ammonium, phosphorus, dissolved organic carbon and organic matter. These numbers vary greatly with species, sizes, activity, water temperature, season, dissolved oxygen and other environmental conditions. In the term of species, for example, the ratio of protein to energy must be determined separately for each fish species in order to create an effective diet. Properly formulated prepared feeds have a well-balanced energy to protein ratio. Similarly, feeding activity should be paid attention by the fish farmers in order to help determine feed acceptance, calculate feed conversion ratio and feed efficiencies (Craig and Helfrich, 2002).

In intensive production marine aquaculture such as flow-through systems and cages, most of the waste water from flow through systems is not treated (Metaxa et al., 2006) and the waste water is flushed out directly to the environment by water exchange (van Rijn et al., 2006). Further-more, the high nutritional status in the ecological aspect may significantly cause a series of ecological events, including eutrophication (PérezMayorga et al., 2011) such as red tides, green tides and other disasters (Glibert et al., 2011; Schumacher et al., 2014).

One effort to reduce this waste is by using integrated aquaculture system. In integrated aquaculture system, by-products (wastes) from one species become nutrients for other cocultured species (Hussenot, 2006). The integration of finfish aquaculture with seaweed culture is one such practice for reduction of pollution (Al-Hafedh et al., 2014) and lead to a sustainable aquaculture (Crab, 2007). In addition, algae require dissolved $\mathrm{N}$ for their growth (Neori et al., 2004). Moreover, the nutrients could be transformed into valuable products or flushed out from the system (Chopin et al., 2010).

The criteria of seaweed to an integrated aquaculture operation are the rapid growth, the accumulation of $\mathrm{N}$ and some added value (Neori et al., 2004). Ulva prolifera is an edible green alga that grows in river mouths and brackish inner bays, used as a foodstuff in Japan, has dark green in color and strong flavor as compared to other Ulva species as well as has high commercial value as a food source for humans (Ohno, 1993). This algae species can proliferate rapidly has fast growth rates in the eutrophic ecosystems and also has rapid uptake and assimilation of nutrients (Cohen and Fong, 2006).

As part of an effort to develop integrated aquaculture technology, Al Hafedh et al. (2014) had evaluated tank-based integrated system using green alga, Ulva lactuca. However, as the ability of seaweeds for growing depends on several culture conditions, such as the water flow and nutrient concentration (Buschmann et al., 2001). The nutrient uptake efficiency is defined as the average reduction $(\%)$ in the nutrient concentration. Meanwhile, the nu-trient uptake rate is the amount of nutrient removed per unit of time. Stocking densities and water turnover rate greatly affect the two concepts for a certain period. (Buschmann et al., 2001).

In tank culture, water flow is an important aspect to managing nutrient availability. By increasing the water flow, nutrient flux increases that determine that seaweeds will not be nutrient limited, permitting a higher biomass production, and in this condition, the nutrient uptake efficiency will be lower. Moreover, if the flow rate is low, nutrients will become limiting, biomass production will decrease, but the nutrient uptake efficiency will be higher. Consequently, it is essential to establish the main target of the culture to intend to optimize its functioning (Buschman et al., 2001). Therefore, It is important to utilize the physiological potential of the seaweed to design an efficient integrated aquaculture system (Troell et al., 2003). Al-Hafedh et al. (2014) found that effluent flow rate has a significant impact on the performance of seaweed than stocking density. This experiment had been applied on Yellowtail Seriolla quinqueradiata and Seaweed Ulva prolifera. 


\section{METHODS}

\subsection{Integrated Aquaculture System}

Integrated aquaculture system was installed at Usa Marine Biological Center, Kochi University as a layout described in Figure 1. The system consisted of one rectangular fish culture tank (1.5 m length, 0.9 $\mathrm{m}$ width, 0.6 height and 0.4 depth, total volume approximately $540 \mathrm{~L}$ ), one rectangular sediment tank (0.8 m length, 0.6 width, $0.4 \mathrm{~m}$ depth, total volume approximately $192 \mathrm{~L})$ and six round seaweed culture tanks (each with total volume $30 \mathrm{~L}$ ). The fish tank was covered by a net and plastic roof to avoid direct sunlight. Fish tank and seaweed tank were aerated using air stones connected to a $13 \mathrm{~mm}$ pipe with an air blower (Hi blow air pump $17.7 \mathrm{kpa}, 120 \mathrm{~L} / \mathrm{min}$, the Phillippines).

\subsection{Experimental Set-up}

The experimental fish culture tank was watered with non-filtered seawater from USA bay about $10 \mathrm{~L} \mathrm{~min}^{-1}$ and stocked with 5,095 $\mathrm{g}$ of the 9 fish with an average weight of $566.11 \pm 81.51 \mathrm{~g}$ (Fig. 1A). Water was flowed continously from the sea to the fish tank (Figure 1A) and subsequently to sedimentation tank (Figure 1B) and finally to seaweed tanks (Figure 1C) in a water flow-through model. Growth performance and feed utilization of the fish were determined and calculated by using the following formulae: Daily weight gain $\left(\mathrm{DWG} ; \mathrm{g} \mathrm{day}^{-1}\right)=($ final weight - initial weight) / no.of fish / time (days); Feed conversion ratio $(\mathrm{FCR})=$ feed intake (g) / weight gain (g).

In this study, Ulva prolifera with the length of $1 \mathrm{~cm}$ was obtained from seaweed laboratory, Kochi University. The initial protein content of this seaweed was $5.63 \%$ (in dry weight). The seaweed was cultivated in 3 different tanks (with a different flow rate of $0.5 \mathrm{~L} \mathrm{~min}^{-1}, 1 \mathrm{~L} \mathrm{~min}^{-1}$ and $1.5 \mathrm{~L} \mathrm{~min}^{-1}$, low, medium and high flow rate) in two replicates to seaweed.

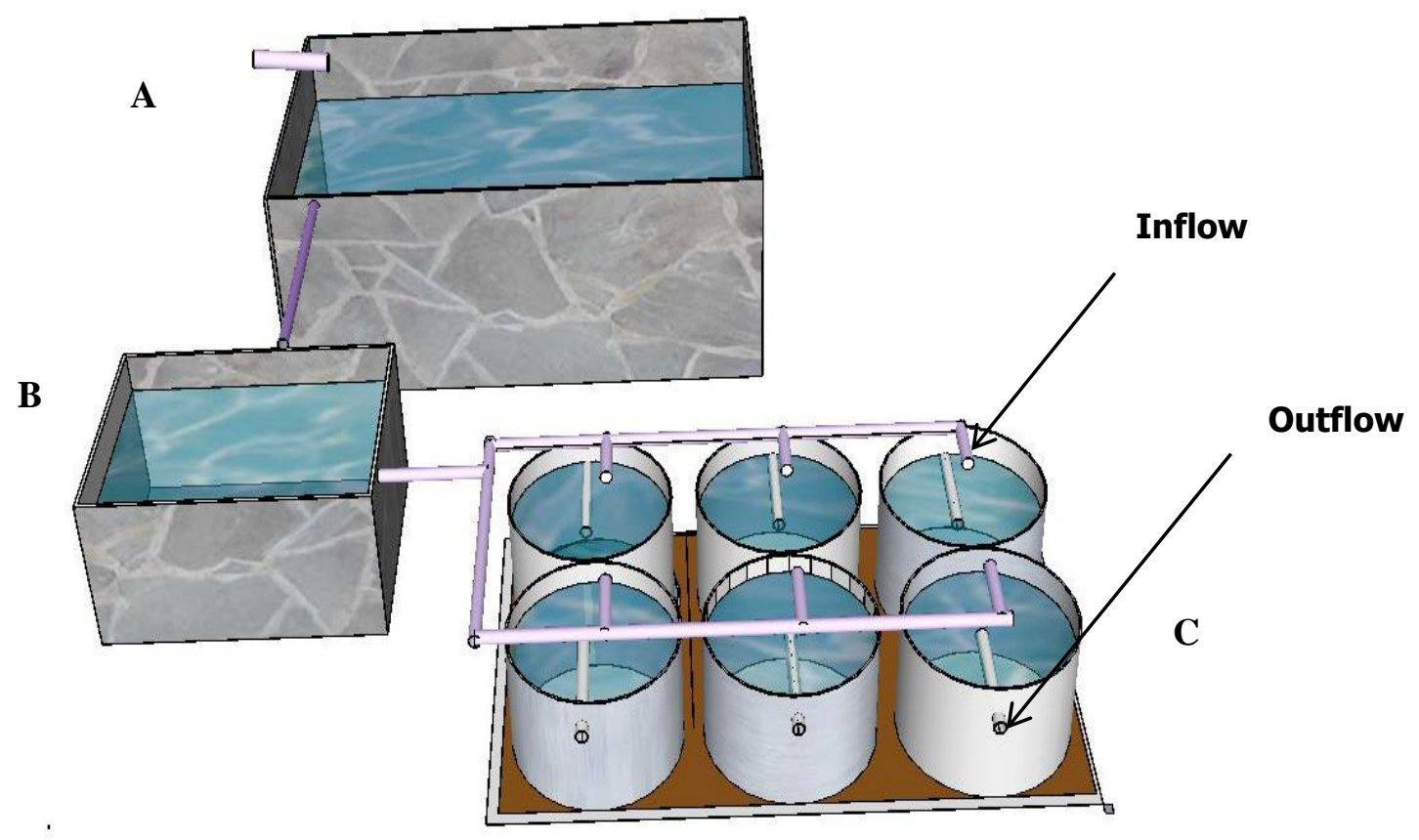

Figure 1. The integrated tank-based aquaculture system for the marine fish and seaweed culture experiments. A. fish tank, B. sediment tank, C. seaweed tanks. 
The seaweed was stocked at a stocking density of approximately $0.83 \pm 0.02 \mathrm{~g}$ in each $30 \mathrm{~L}$ seaweed tank. Seaweed was set up with strong aeration thus allowing the seaweed floated in the water column (Hiraoka and Oka, 2008).

The fish were fed once daily at 10.00 am (6 days a week) with a commercial diet (Nisshin marubeni feed co, Japan) containing $42 \%$ protein until satiation, and total feed given per day was recorded. A long pipe was used to siphon solids from the bottom of sedimentation tank. The airflow was adjusted to be strong enough to enable the rotation of seaweed. The seaweed tank was cleaned every 3 days, at the same time seaweed biomass was weighed. The experiment was conducted in 24 days for growth performance of seaweed.

\subsection{Growth Performance of Seriolla quinqueradiata and Ulva prolifera}

Initial and final fish weight were measured by using a balance. Fresh weight of the seaweeds was determined after removal of any visible mud on their surface and after 3 days all the seaweed in each tank were taken by a net with mesh size $(0.5 \mathrm{~cm})$. They were rinsed under running seawater and shook until they were completely clean. Afterward, the seaweed was dried with washing machine for approximately 3 minutes and weighed, and subsequently put them back to the original tank.

Net yield (NY) expressed as wet weight day $^{-1}$ and daily growth rate (DGR) expressed as \% wet weight day $^{-1}$ was determined according to Sahoo et al. (2002) and calculated as: NY ( $\mathrm{g}$ wet weight day $\left.^{-1}\right)=$ (final biomass - initial biomass)/ time (days), DGR $(\%)=\left[\ln \mathrm{W}_{\mathrm{t}}-\ln \mathrm{W}_{0}\right] / \mathrm{d} \times 100$. Where $\mathrm{W}_{0}$ and $\mathrm{W}_{\mathrm{t}}$ were the initial and final wet weights in grams respectively, $t$ is days of culture.

\subsection{Protein Content of Ulva prolifera}

At the end of the experiment, sample collection was conducted to determine the quality of the seaweed. The seaweed tissues from each tank in the integrated aquaculture system were stored in freezer at $-30^{\circ} \mathrm{C}$. Furthermore, at the analysis time they were dried at $60^{\circ} \mathrm{C}$ for 24 hours and then stored in a dry place until protein determination at Fish Nutrition laboratory, Kochi University. All samples were analyzed according to the method described by Takeuchi (1988) and determined by using Kjeldahl.

\subsection{Water Quality Monitoring}

Temperature and dissolved oxygen were measured in situ by using DO meter (multi HQ 40 d multimeter, USA) during sampling. The daylight lasting was 9 hours and 57 minutes. Water samples were collected at the outflow fish tank, inflow and outflow seaweed tank to measure total ammonianitrogen (TAN). Sampling was carried out once on day 20 at 0 h, 2 h, 4 h, 6 h, 8 h, 10 h, $12 \mathrm{~h}, 18 \mathrm{~h}, 21$ and $24 \mathrm{~h}$ after feeding. Furthermore, the water samples were kept in freezer $-30{ }^{\circ} \mathrm{C}$ until analyzed. The ammonia$\mathrm{N}$ content was determined by phenate method (Strickland and Parsons, 1972) and using autoanalyzer-spectrophoto-meter (SWAN version 1.41 BLTEC) at the Core Center, Kochi University.

\subsection{Statistical Analysis}

Data analyses were performed using variance (ANOVA) with $\mathrm{F}$ test at $95 \%$ confidence interval using the program Ms. Exel and SPSS 20.0. The further test of the difference among the treatments could be performed using Tukey test (Steel and Torrie, 1993).

The parameters analyzed were included the weight and growth rate of seaweed and yellow tail, the survival rate of yellow tail and ammonia content. Water quality data were analyzed descriptively.

\section{RESULTS AND DISCUSSION}

\subsection{Results}

The fish were fed at satiation. Initial and final average weights of the fish during 
Table 1. Seriola quinqueradiata stocking and growth data in the integrated aquaculture system.

\begin{tabular}{lc}
\hline \multicolumn{1}{c}{ Parameters } & Values \pm Standard Deviation \\
\hline Average initial fish weight $(\mathrm{g})$ & $566.11 \pm 81.51$ \\
Average final fish weight $(\mathrm{g})$ & $600.89 \pm 87.79$ \\
Total initial fish biomass $(\mathrm{g})$ & 5,095 \\
Total final fish biomass $(\mathrm{g})$ & 5,408 \\
Culture period (days) & 24 \\
Weight gain $\left(\mathrm{g}\right.$ fish day $\left.^{-1}\right)$ & 1.45 \\
Total gain $(\mathrm{g})$ & 313 \\
Total feed consumed $(\mathrm{g})$ & 778.5 \\
Feed conversion ratio (FCR) & 2.49 \\
Survival Rate $(\%)$ & 100 \\
\hline
\end{tabular}

the experiment were $566.11 \mathrm{~g} \mathrm{fish}^{-1}$ and $600.89 \mathrm{~g} \mathrm{fish}^{-1}$, respectively (Table 1 ). Total initial fish biomass was $5,095 \mathrm{~g}$, and the final fish biomass was $5,408 \mathrm{~g}$. During 24 days rearing in the integrated system, the fish weight increased. The daily weight gain and total gain were $1.45 \mathrm{~g}$ fish day $^{-1}$ and $313 \mathrm{~g}$, respectively. Feed intake was $778.5 \mathrm{~g}$, and the value for FCR was obtained to be 2.49 .

Growth and fresh biomass production of the green seaweed, Ulva prolifera were compared at three different flow rates $(0.5 \mathrm{~L}$ $\mathrm{min}^{-1}, 1.0 \mathrm{~L} \mathrm{~min}^{-1}$ and $1.5 \mathrm{~L} \mathrm{~min}^{-1}$ ) (Fig. 2). Ulva prolifera yield achieved values of $42 \mathrm{~g}$ at low flow rate, $156 \mathrm{~g}$, and $155 \mathrm{~g}$ at medium and high flow rates, respectively.

The biomass of the Ulva was not significantly different between medium and high flow rate $(P>0.05)$. It means that flow rates of $1.0 \mathrm{~L} \mathrm{~min}^{-1}$ and $1.5 \mathrm{~L} \mathrm{~min}^{-1}$ obtained the same biomass statistically. However, the medium and high flow rates were statistically significant difference with low flow rate $(P<0.05)$ and had the higher value 3.7 times.

At the same time, the daily growth rate reached values of $16.40 \% \mathrm{~d}^{-1}$ at low flow rate, $21.87 \% \mathrm{~d}^{-1}$ and $21.74 \% \mathrm{~d}^{-1}$ at medium and high flow rates (Fig.3).

Furthermore, the daily growth rate of this seaweed was not significantly different between medium and high flow rate $(P>0.05)$. These values were statistically significant difference with low flow rate $(P<0.05)$. This tendency was similar with the biomass values.

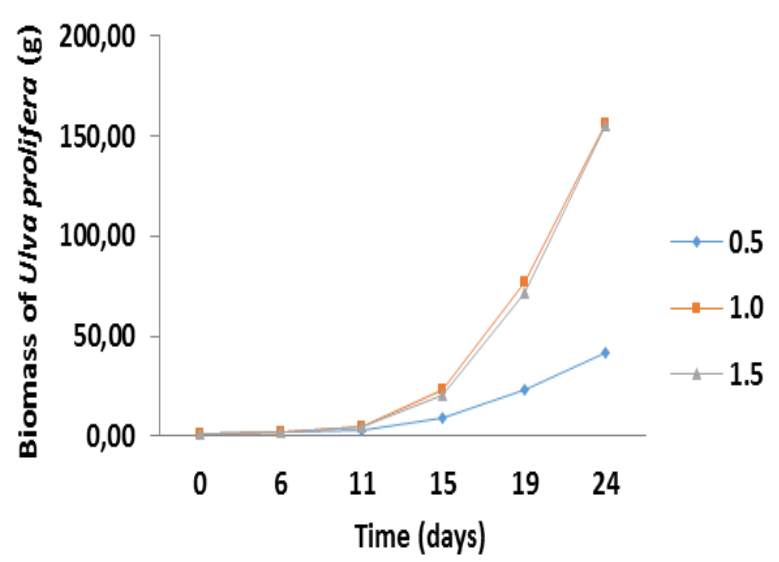

Figure 2. Mean ( \pm standard deviation; $n=2)$ of the biomass of Ulva prolifera at different flow rates $\left(0.5 \mathrm{~L} \mathrm{~min}^{-1}(\diamond)\right.$, $1 \mathrm{~L} \mathrm{~min}^{-1}(\mathbf{\square})$ and $\left.1.5 \mathrm{~L} \mathrm{~min}^{-1}(\boldsymbol{\Delta})\right)$.

The protein content of Ulva cultured with fish effluent at different flow rate did not significantly different $(P>0.05)$ and had the values about 25-27.5\% (Fig.4). Protein content of this seaweed at the end of the maintenance for 24 days increased approximately 4.4 to 4.9 times. This value indicates that the nitrogen in water affected the growth of seaweed.

Figure 5 showed that the nutrient in the fish tank inlet from non-filtered seawater within 24 hour was low and ranged $0.0020-$ $0.0113 \mathrm{mg} \mathrm{N} \mathrm{L}^{-1}$. It means that the source of water applied in this study had the same amount of nutrients. After passing through the fish tank, the range value of nutrients in the 


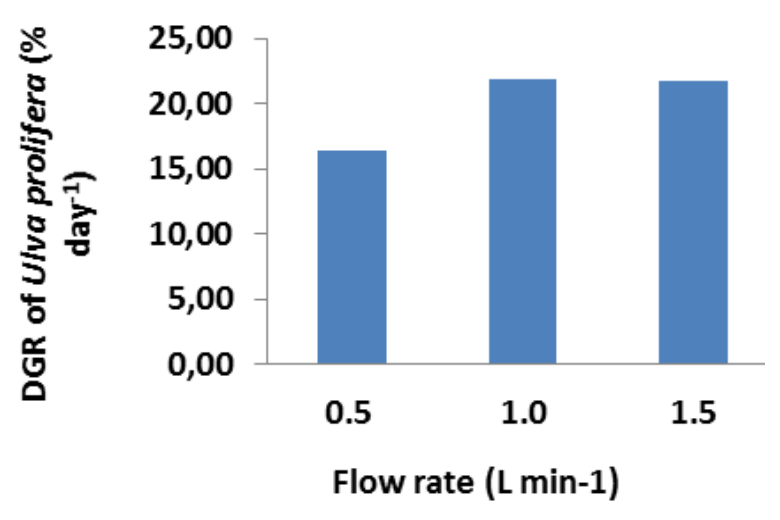

Figure 3. Mean ( \pm standard deviation; $\mathrm{n}=2$ ) of daily growth rate of Ulva prolifera at different flow rates $(0.5$ $\mathrm{L} \min ^{-1}(\diamond), 1 \mathrm{~L} \min ^{-1}(\boldsymbol{\varpi})$ and $1.5 \mathrm{~L}$ $\left.\min ^{-1}(\boldsymbol{\Delta})\right)$.

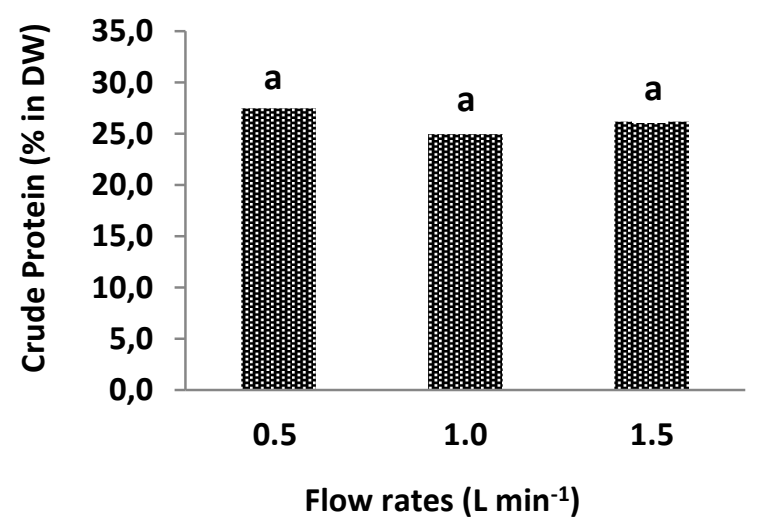

Figure 4. Crude protein content (\% in DW) of Seaweed Ulva prolifera cultured at different flow rates with fish culture outflow water.

water inflow of the seaweed tank within 24 hours was $0.0286-0.1394 \mathrm{mg} \mathrm{N} \mathrm{L}{ }^{-1}$. Total ammonia nitrogen (TAN) in the inlet water of seaweed tanks showed not significantly different value $(P>0.05)$ at different flow rate.

However, after it passed through the sedimentation tank and seaweed tank, the nutrient content was reduced to be 0.0202 $0.1137 \mathrm{mg} \mathrm{N} \mathrm{L}^{-1}$ (Fig.6). This result proves that the seaweed could absorb ammonia properly. The source of nutrients reached the maximum level at 4-8 hours after feeding. Meanwhile, temperature and dissolved oxygen measured were in the ranges of

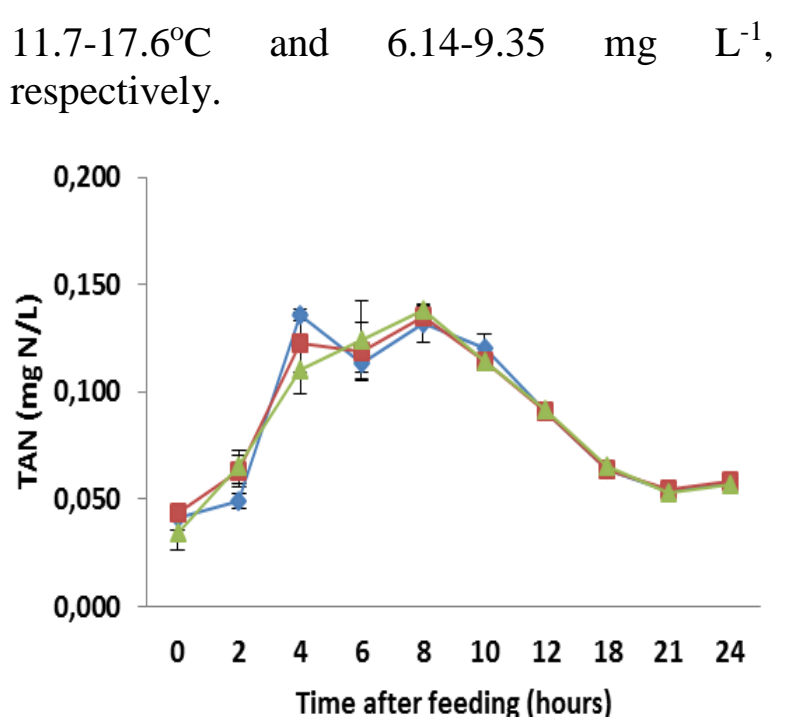

Figure 5. Total ammonia nitrogen (TAN) of yellow tail Seriolla quinqueradiata in the inlet water of seaweed tanks at different flow rates $\left(0.5 \mathrm{~L} \mathrm{~min}^{-1}\right.$ $(\diamond), 1 \mathrm{~L} \mathrm{~min}^{-1}(\mathbf{a})$ and $1.5 \mathrm{~L} \mathrm{~min}^{-1}$ $(\boldsymbol{\Delta}))$ in day 20 .

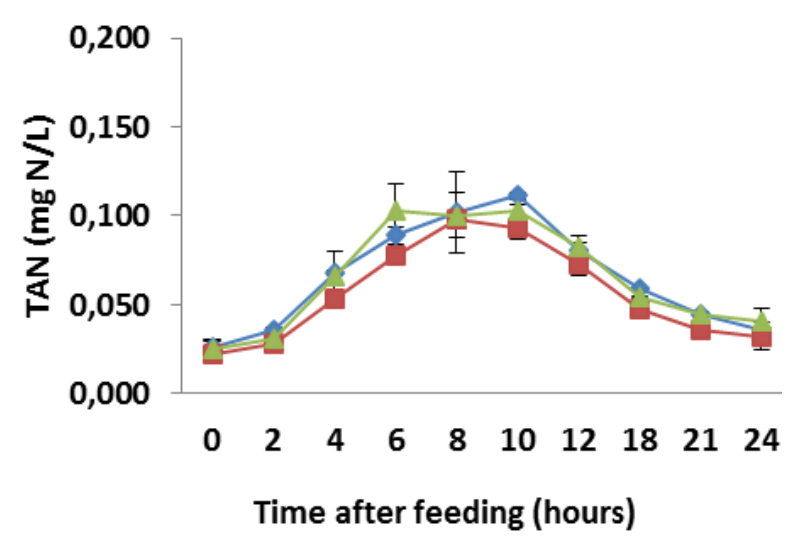

Figure 6. Total ammonia nitrogen (TAN) of yellow tail Seriolla quinqueradiata in the outlet water of seaweed tanks at different flow rates $\left(0.5 \mathrm{~L} \mathrm{~min}^{-1}\right.$ $(\diamond), 1 \mathrm{~L} \mathrm{~min}^{-1}(\mathbf{\square})$ and $1.5 \mathrm{~L} \mathrm{~min}^{-1}$ $(\boldsymbol{\Delta}))$ in day 20 .

\subsection{Discussion}

Ulva prolifera has potential as a tool for bioremediation because they have the characteristics of opportunistic, i.e. high growth rates and easy to be maintained across a broad range of environments (Fan et al., 
2014). Natural populations of $U$. prolifera in Japan occur only in limited location during a short period, especially in early spring. Furthermore, wild stocks of this alga have been decreasing due to water pollution (Ohno and Miyanoue, 1980). All needs for consumption of Ulva come from cultivated stock (Dan et al., 2002). However, annual cultivated production of $U$. prolifera has fluctuated due to salinity and temperature (Pandey and Ohno, 1985). Threfore to establish a stable tank mass culture of $U$. prolifera, Hiraoka and Oka (2008) conducted an experiment about new "germling cluster", a method for tank cultivation of $U$. prolifera in a free-floating form, by using Deep Sea Water (DSW) with constant salinity, inorganic nutrient status and temperature. This method, using a large number of young germlings, removes the risk of decay by reproductive maturation, because younger thalli seldom form zoids.

Effect of nitrogen source content with a flow rate in this study showed that $\mathrm{NH}_{3}$ content was relatively similar to in the inlet water of the seaweed (Fig. 5), then the trend value was the same for all outlets. Thus, the cause of the different results was the flow rates used in this study. In this regard, $\mathrm{NH}_{3}$ did not have a significant impact on the water content of seaweed outlet. This can be evidenced by the same value of $\mathrm{NH}_{3}$ at the outlet of seaweed among the treatments (Fig. $6)$.

Flow rates of $1.0 \mathrm{~L}$ min and $1.5 \mathrm{~L} \mathrm{~min}^{-}$ ${ }^{1}$ in this study obtained biomass of $156 \mathrm{~g}$ and $155 \mathrm{~g}$. However, the biomass of the seaweed only reached $42 \mathrm{~g}$ on a flow rate of $0.5 \mathrm{~L} \mathrm{~min}^{-}$ ${ }^{1}$. It indicates that the higher the value of the flow rate was applied, then the higher the growth of seaweed was obtained. Likewise, DGR of $1.0 \mathrm{~L}$ min and $1.5 \mathrm{~L} \mathrm{~min}^{-1}$ yielded in this study were not significantly different $(P>0.05)$, with the values of $21.87 \%$ and $21.76 \%$ respectively. In this study, seaweed was cultured in $30 \mathrm{~L}$ tanks with the initial biomass of $0.83 \mathrm{~g}$ each tank. However, the final biomass of $1.0 \mathrm{~L} \mathrm{~min}^{-1}$ and $1.5 \mathrm{~L} \mathrm{~min}^{-1}$ were 3.7-fold from flow rate of $0.5 \mathrm{~L} \mathrm{~min}^{-1}$. These experiments suggest that an increment of the flow rates in seaweed culture tanks allowed to almost 200 times the biomass yield obtained in 24 days experiment.

Considering the results described above, it can be stated that the increase in water flow to $1.0 \mathrm{~L} \mathrm{~min}^{-1}$ and $1.5 \mathrm{~L} \mathrm{~min}^{-1}$ is adequate to maintain a high yield. The flow rates indicated changes in water flow or velocity in the seaweed tanks. In this study, Ulva prolifera maintained at $30 \mathrm{~L}$ tank, could grow optimally at flow rate of $1.0 \mathrm{~L} \mathrm{~min}^{-1}$. The results mentioned in advance could be positively related to retention time. In this regard flow rate of $1.0 \mathrm{~L} \mathrm{~min}^{-1}$ in this study need $100 \%$ water turnover for $30 \mathrm{~L}$ seaweed tank in appropriate time about 30 minutes to absorb nutrient well. Subsequently, this result was not significantly different with the growth performance of seaweed cultured at $1.5 \mathrm{~L}$ $\min ^{1}$, even though they need a water turnover for once circulation approximately 20 minutes. Thus, to make efficient of the amount of water wasted in the culture process, it is suggested that the optimum flow rate in this study was $1 \mathrm{~L} \mathrm{~min}^{-1}$. Meanwhile, Al Hafedh $e t$ al. (2014) found that Ulva lactuca maintained on a volume of $1 \mathrm{~m}^{3}$ could grow optimally at a flow rate of $10 \mathrm{~m}^{3} \mathrm{day}^{-1}$ and was needed 2.4 hours for $100 \%$ water exchange. Water motion is extremely important for seaweed because it determines the thickness of velocity and diffussion boundary layers (DBL's) around the thallus and leads the movement of ions and gasses to and from the thallus surface (Hurd, 2000). Photosynthesis rates are also reduced under slow flow (Koch, 1993). This is in accordance with Gao et al. (1992), that the basic principle seaweed technology has been the vertical movement, by bottom aeration, of seaweed suspensions in tanks and ponds, and the passage of nutrient-laden water through them. The vertical movement of an optimally stocked seaweed pond allows each algal frond to be exposed to an optimal light exposure. The water turbulence generated by the aeration thins the hydro boundary layer 
around the frond surface, speeding the inflow to the fronds of nutrients and outflow from the frond of excess oxygen.

The DGR results in the present study were higher than that reported in the previous study by Al-Hafedh et al. (2014) with maximum value only $10.60 \%$ on Ulva lactuca. Probably because flow rates used in this study was higher than the flow rates they applied. The growth rate obtained in this study was also higher than that obtained by Msuya et al. (2006) which found that Ulva reticulata grew at an average of $4.0 \%$ per day during the treatment (fishpond outflow channel). In addition, $U$. clathrata that was cultured in tanks receiving waste water from a shrimp aquaculture pond showed daily growth rate attaining 12\%, (Copertino et al., 2009). Another study from Ale and Mikkelsen (2011) found that Ulva lactuca maximum growth rates $\left(13.8 \% \mathrm{~d}^{-1}\right)$ were recorded at the lowest density $\left(1.5 \mathrm{~g} \mathrm{FW}^{-1}\right)$. Yield reached a maximum $\left(40 \mathrm{~g} \mathrm{DW} \mathrm{m}^{-2} \mathrm{~d}^{-1}\right)$ at a density of $2.5 \mathrm{~g} \mathrm{FW} \mathrm{1}^{-1}$, decreasing at higher densities (6 g FW ${ }^{-1}$ ) to least than $10 \mathrm{~g} \mathrm{DW} \mathrm{m}^{-2} \mathrm{~d}^{-1}$. Another author, Nelson et al. 2001 reported that increase in seaweed production depends on the location where they will receive waste water from the adjacent fishponds.

In tank culture, waterflow is important aspect to manage nutrient availability. By increasing the water flow, nutrient flux increases that determines that seaweeds will not be nutrient limited, permitting a higher biomass production, and in this condition, the nutrient uptake efficiency will be lower (Fig.7). Moreover, if the flow rate is low, nutrients will become limiting, biomass production will decrease, but the nutrient uptake efficiency will be higher. A high water turnover specifies a high biomass production capacity, as nutrients are not a limiting factor, however the biofiltering efficiency will decrease. On the other hand if the water turnover rate is reduced, nutrient will begin limited, that making a lower capacity for the algae grow, but an increase of the biofiltering efficiency (Buschman et al., 2001).

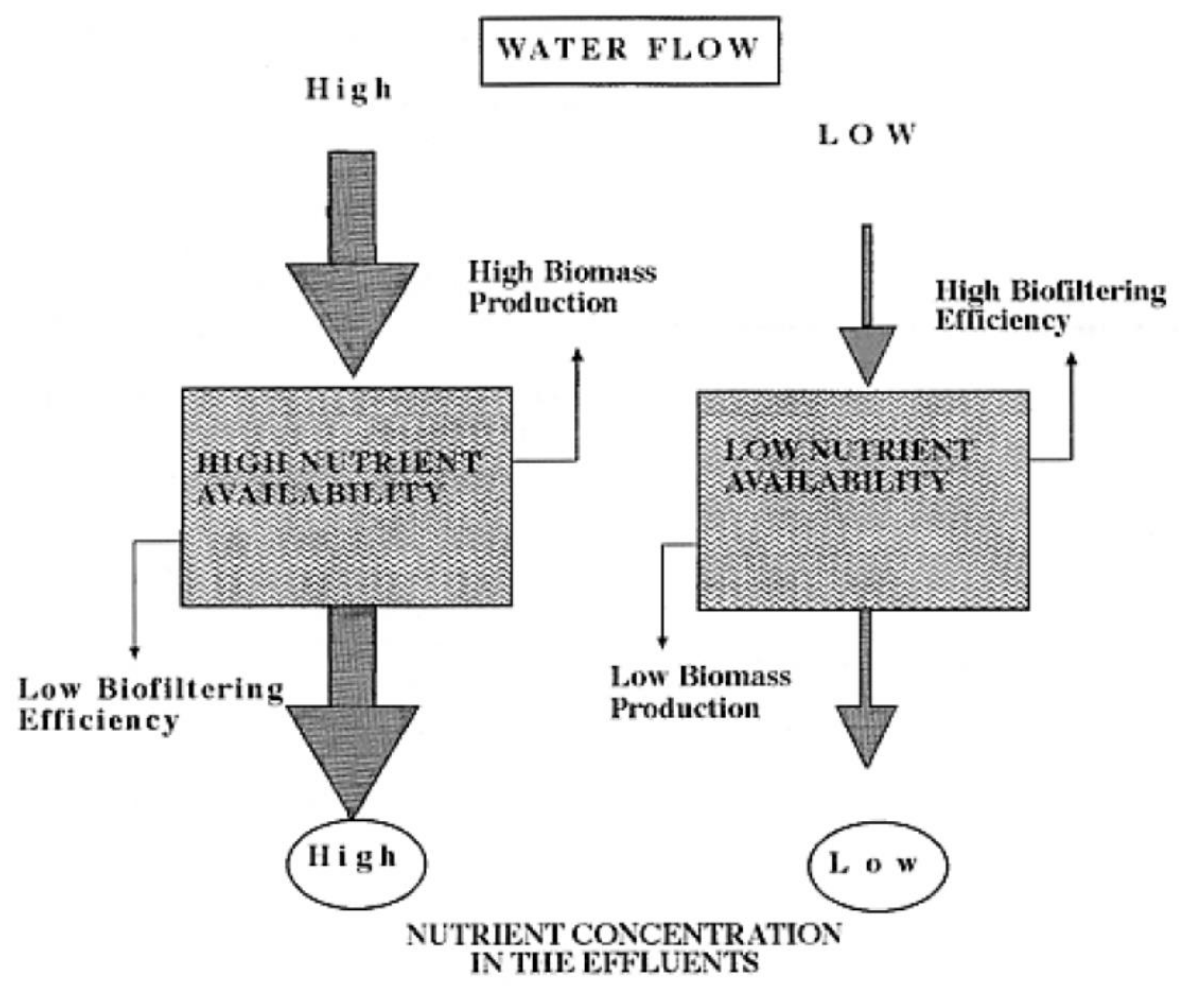

Figure. 7 General showing the effect of the water turnover rate on growth and biofiltering efficiency (Buschman et al., 2001). 
Based on Figure 4, the flow rate did not affect nitrogen content of the seaweed as well as the nutrient content of the water source did not affect the growth. The nutrient values of the seaweed were the same at different flow rates because the flow rate did not affect nutrient absorption by the seaweed. The content of nutrient sources used was high using effluent from the fish tank with a range value of $0.0286-0.1394 \mathrm{mg} \mathrm{N} \mathrm{L}^{-1}$ so that the protein contents of the seaweed at the flow rates of $0.5 \mathrm{~L} \mathrm{~min}^{-1}, 1.0 \mathrm{~L} \mathrm{~min}^{-1}$, and $1.5 \mathrm{~L}$ $\min ^{-1}$ were $27.5 \%, 25.0 \%$ and $26.2 \%$, respectively. These results were higher than those of previous studies conducted by Dhargalkar and Pereira (2005) $19.5 \%$ and Mamatha et al. (2007) $21 \%$.

The protein contents of the Ulva at the end of the experiment were the same because the seaweed got the same nutrient sources from fish tank effluent. Then, the effluent was distributed into 3 different flow rates with 2 replications. This causes nutrient values generated in Ulva also similar in each treatment. However, the protein contents of this seaweed at the end of maintenance for 24 days increased approximately 4.4 to 4.9 times. This value indicates that the nitrogen in water affected the growth of seaweed. Although the protein values were not significantly different between treatments. However, the protein harvested at the end of the maintenance was different each treatment. It can be seen from the protein obtained by biomass converted so that the effectiveness values of the use of different flow rate were different. Protein content on flow rate of $0.5 \mathrm{~L}, 1.0 \mathrm{~L}$ and $1.5 \mathrm{~L}$ $\min ^{-1}$ had different effectiveness values namely, $11.54 \%, 38.96 \%$ and $40.83 \%$, respectively. Therefore, it could be said that the harvested protein was higher on flow rates of $1.0 \mathrm{~L}$ and $1.5 \mathrm{~L} \mathrm{~min}^{-1}$.

Ammonia, a chemically reduced compound, is assimilated as much as two to three times faster than the oxidized nitrate by many types of seaweed (Neori, 1996; Ahn et al., 1998). The most important sources of nitrogen for seaweeds are $\mathrm{NH}_{4}{ }^{+}$and $\mathrm{NO}_{3}{ }^{-}$and, to a lesser extent, $\mathrm{NO}_{2}{ }^{-}$(Lobban and Harrison 1997). Theoretically, $\mathrm{NH}_{4}{ }^{+}$ought to be superior because it can be directly assimilated into amino acids, while nitrate must be reduced prior to amino acid construction (Barsanti and Gualtieri, 2006).

Ammonium $\left(\mathrm{NH}_{4}^{+}\right)$and ammonia $\left(\mathrm{NH}_{3}\right)$, with the unionized moiety toxic to marine finfish at concentrations around 0.05 $\mathrm{mg} \mathrm{L}^{-1}$ (Person-Le Ruyet et al., 1997, Foss et $a l ., 2009)$. Bacterial biofilters are the most common method of converting harmful ammonia to relatively non-toxic nitrate ( $\mathrm{NO}_{3}{ }^{-}$; Timmons et al., 2002). The microbial oxidation of ammonia (nitrification). Therefore diminishes the performance of the integrated system (Krom et al., 1995; Schuenhoff et al., 2003) and should be avoided. Maintaining the cleanliness of all wet surfaces, including those of pipes, helps prevent the development of nitrifying bacteria (Dvir et al., 1999). The maximal biofiltration of any nutrient occurs, of course, in daytime, yet some TAN is also taken up at night, particularly when the TAN load to the algae is low (Cohen and Neori, 1991; Schuenhoff et al., 2003).

Integrating seaweed into the system is an alternative means to deal with waste nitrogen, it is a net oxygen producer during daylight hours, and it yields marketable biomass. Seaweed integration within landbased aquaculture systems has the potential to improve water quality for finfish cultivation, reduce effluent nutrient concentrations, and increase operational income product diversification. Algal uptake of nitrogen depends on numerous factors including physical factors namely (light and temperature), environmental nutrient concentration, intracellular nutrient concentrations and biological factors (metabolism, age, etc). Studies on nitrogen form preferences are conflicting. Several studies on nitrogen enrichment of Ulva sp. show that ammonium $\left(\mathrm{NH}_{4}^{+}\right)$is physiologically preferred over nitrate $\left(\mathrm{NO}_{3}{ }^{-}\right)$given that less energy is required for its assimilation into the algal 
biomass (Fujita, 1989). Macroalgae also show higher growth rate with $\mathrm{NH}_{4}{ }^{+}$than with $\mathrm{NO}_{3}{ }^{-}$ (DeBoer et al., 1978). Ale et al. (2011) reported that ammonium is favorably assimilated by Ulva lactuca; giving rise to a higher relative growth rate (RGR) and biomass yield and the uptake rate of ammonium is higher than that of nitrate.

Algae generally absorb nitrogen gradually, namely: ammonium > nitrate > nitrite. Utilization of nitrate and nitrite by seaweed is less efficient because of nitrates and nitrites must first be reduced before it is used by cells of the seaweed. Nitrate is used by seaweed for metabolism by the reductase nitrate enzyme obtained (Patadjai, 1993). Absorption of nitrate and nitrite by seaweed is affected by the concentration of ammo-nium in the media.

FCR is a measure of fish efficiency in converting feed mass into increases of the desired output. FCR indicates the efficiency of feed utilization by fish and affects waste load discharged into the aquatic environment. Contributions of $\mathrm{N}$ derived from the feed to the waste load will be influenced by FCR and nutrient retention in fish biomass.

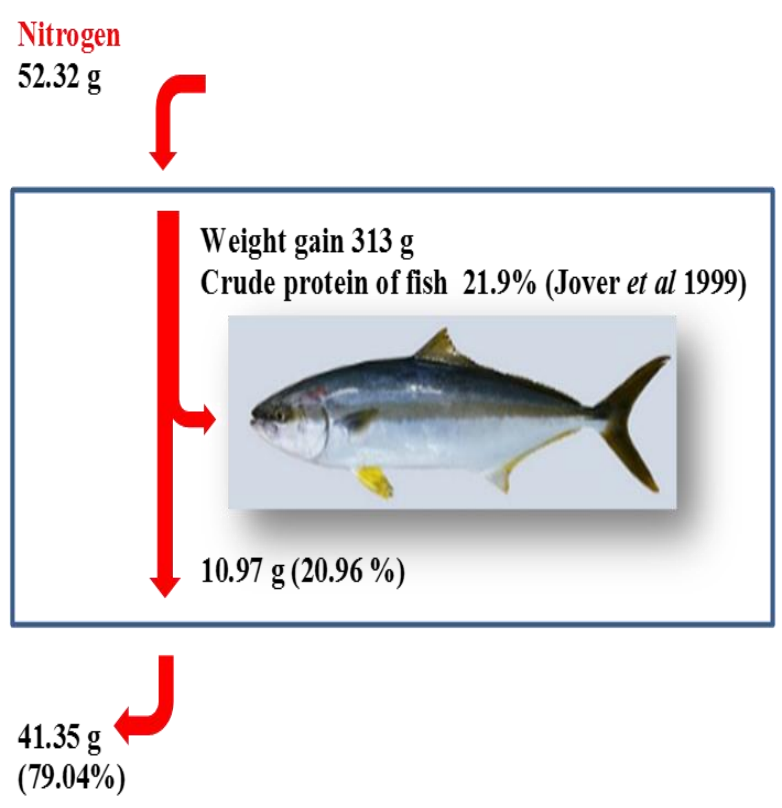

Figure 8. Influx and efflux of nitrogen in yellowtail culture.
Differences in the amount of Nitrogen in the feed and fish produced were the amount of $\mathrm{N}$ loading into fish culture tank. FCR obtained in this study was 2.49 with $42 \%$ protein feed. To grow fish with the weight of $566.11 \mathrm{~g}$ to $600.89 \mathrm{~g}$ was removed waste as much as $41.35 \mathrm{~g} \mathrm{~N}$ (Figure 8).

The waste nitrogen could be used to produce new products such as Ulva prolifera as much as $42 \mathrm{~g}$ on the flow rate of $0.5 \mathrm{~L} \mathrm{min-}$ $1,156 \mathrm{~g}$ and $156 \mathrm{~g}$ at the flow rates of 1.0 and $1.5 \mathrm{~L} \mathrm{~min}-1$, respectively so that the quality of the culture tank will remain good. Furthermore, the residual waste as much as $26.82 \mathrm{~g} \mathrm{~N}$ still remaining in the water.

\section{CONCLUSION}

The seaweed $U$. prolifera can be cultured in integrated aquaculture system. Flow rates of $1.0 \mathrm{~L} \mathrm{~min}^{-1}$ and $1.5 \mathrm{~L} \mathrm{~min}^{-1}$ obtained biomass of $156 \mathrm{~g}$ and $155 \mathrm{~g}$, respectively. The flow rate affected the growth of the seaweed. However, the flow rate did not affect nitrogen content of the algae.

\section{ACKNOWLEDGMENTS}

W.A.D. was sponsored by the JASSO (Japan Student Services Organization) and SUIJI-JDP (Six Universities Initiative Japan Indonesia-Join Degree Program) during following student exchange program at Kochi University, Japan. The part of this research was conducted by The Kochi University President's Discretionary Grant. We thank to Prof. M. Hiraoka of Kochi University for help and advice.

Thanks for help by Prof. Kei Okamura, Ms. Mayumi Hatta from Laboratory of Marine Environment, Center for Advanced Marine Core Research, Kochi University, Japan, as well as Mr. Yasuaki Matsumoto, Ms. Kanako Kunisawa, Mrs. La Xuan Thao, Ms. Siripon Tola, Mr. Takamori Fusamae, Mr. Thinh Do Van, Mr. Toshikazu Mori and Mr. Hiroumi Imahashi. 


\section{REFERENCES}

Ahn, O., R.J. Petrell, and P.J. Harrison, 1998. Ammonium and nitrate uptake by Laminaria saccharina and Nereocystis luetkeana originating from a salmon sea cage farm. J. of Applied Phycology, 10:333-340.

Ale, M.T. and J.D. Mikkelsen. 2011. Differential growth response of Ulva lactuca to ammonium and nitrate assimilation. J. of Applied Phycology, 23:345-351.

Al-Hafedh, A. Alam, and A.H. Buschmann. 2014. Bioremediation potential, growth and biomass yield of the green seaweed, Ulva lactuca in an integrated marine aquaculture system at the Red Sea coast of Saudi Arabia at different stocking dencities and effluent flow rates. Reviews in Aquaculture, 6:1-11.

Barsanti L. and P. Gualtieri.2006. Algae: anatomy, biochemistry, and biotechnology. CRC, Boca Raton. 361p.

Buschmann, A.H., M. Troell, and N. Kautsky. 2001. Integrated alga farm-ing: a review. Cahiers de Biologie Marine, 42:83-90.

Butcher, R.W. 1933. Studies on the ecology of rivers. I. On the distribution of macrophytic vegetation in the rivers of Britain. J. Ecol., 21:58-91.

Chopin, T., M. Troell, G.K. Reid, D. Knowler, S.M.C. Robinson, A.H. Buschman, and S. Pang. 2010. Integrated multitrophic aquaculture $2^{\text {nd }}$ ed. Increasing IMTA adoption. Global Aquaculture Advocate. Maga-zines. 17-20pp.

Cohen, I. and A. Neori. 1991. Ulva lactuca biofilters for marine fishponds effluents. Bot. Mar., 34:475-482.

Cohen, R.A. and P. Fong. 2006. Using opportunistic green macroalgae as indicators of nitrogen supply and sources to estuaries. Ecological Applications, 16:1405-1420.
Copertino, M.D, T. Tormena, and U. Seeliger. 2009. Biofiltering efficiencyuptake and assimilation rates of Ulva clathrata (Roth) J. Agardh (Clorophyceae) cultivated in shrimp aquaculture waste water. J. of Applied Phycology, 21: 31-45.

Crab, R., Y. Avnimelech, T. Defoirdt, P. Bossier, and W. Verstraete. 2007. Nitrogen removal techniques in aquaculture for sustainable production. Aquaculture, 270:1-14.

Craig, S. and L.A Helfrich. 2002. Understanding Fish Nutrition, Feeds, and Feeding. Virginia Cooperative Extension. Virginia. 420p.

Dan, A., M. Hiraoka, M. Ohno, and A.T Critchley. 2002. Observations on the effect of salinity and photon fluence rate on the induction of sporulation and rhizoid formation in the green alga Enteromorpha prolifera (Müller) $J$. Agardh (Chlorophyta, Ulvales) Fish Sci., 68:1182-1188.

DeBoer, J.A., H.J. Guigli, T.L. Israel, and C.F.D. Elia. 1978. Nutritional studies of two red algae. 1. Growth rate as a function of nitrogen source and concentration. J. Phycol. 14:261-266.

Dhargalkar, V.K. and N. Pereira. 2005. Seaweeds: promising plants of the millennium. Science and Culture, 71:60-66.

Diana, J.S, H.S. Egna, T. Chopin, M.S. Peterson, L. Cao, and R. Pomeroy. 2013. Responsible aquaculture in 2050: 2050 local conditions and human innovations will be key to success. Bio Science, 63:255-262.

Dvir, O., J. van Rijn, and A. Neori. 1999. Nitrogen transformations and factors leading nitrite accumulation in a hypertrophic marine fish culture system. Mar. Ecol. Progr. Ser., 181: 97- 106.

Fan, X., X. Dong, W. Yitao, Z. Xiaowen, C. Shaona, M. Shanli, and Y. Naihao. 2014. The effect of nutrient 
concentrations, nutrient ratios and temperature on photosynthesis and nutrient uptake by Ulva prolifera: implications for the explosion in green tides. J. Appl. Phycol., 26: 537544

Foss, A., A.K. Imsland, B. Roth, E. Schram, and S. Stefansson. 2009. Effects of chronic and periodic exposure to ammonia on growth and blood physiology in juvenile turbot (Scophthalmus maximus). Aquaculture, 296:45-50.

Gilbert, P.M. and J.M. Burkholder. 2011. Harmful algal blooms and eutrophication. "Strategies" for nutrient uptake and growth outside the Redfield comfort zone. Chin. J. Oceanol. Limnol., 29:724-738.

Hiraoka, M. and N. Oka. 2008. Tank cultivation of Ulva prolifera in deep seawater using a new "germling cluster" method. J. Appl Phycol, 20:97-102.

Hurd, C.L. 2000. Water motion, marine macroalgal physiology and production. J. of phycology. 36:453-472.

Hussenot, J. 2006. Les systemes integres en aquaculture marine: une solution durable pour un meilleur respect de l'environnement littoral. In: Chaussade et al. (eds.). Peche et aquaculture: pour une exploitation durable des ressources vivantes de la mer et du littoral. Presses Universitaires de Rennes. Rennes. 67-68pp.

Koch, E.W. 1993. The effect of water flow on photosynthetic process of the alga Ulva lactuca L. Hydrobiologi, 260: 457-462.

Krom, M.D, S. Ellner, J. van Rijn, and A. Neori. 1995. Nitrogen and phosphorus cycling and transformations in a prototype "non-polluting" integrated mariculture system, Eilat, Israel. Mar. Ecol. Prog. Ser., 118:2536.
Lobban, C.S., P.J. Harrison, and M.J. Duncan. 1985. The physiological ecology of seaweeds cambridge Univ. Press. Cambridge. 242p.

Lobban C.S. and P.J. Harrison. 1997. Seaweed ecology and physiology. Cambridge University Press. New York. 493p.

Mamatha, B.S., K.K. Namitha, A. Senthil, J. Smitha, and G.A. Ravishankar. 2007. Studies on use of Enteromorpha in snack food. Food Chemistry, 10: 1707-1713.

Metaxa, E., G. Deviller, P. Pagand, C. Alliaume, C. Casellas, and J.P Blancheton. 2006. High rate algal pond treatment for water reuse in a marine fish recirculation system: water purification and fish health. Aquaculture, 252:92-101.

Msuya, E.F., M.S. Kyewalyanga, and D. Salum. 2006. The performance of the seaweed Ulva reticulata as a biofilter in a low-tech, low-cost, gravity generated water flow regime in Zanzibar, Tanzania. Aquaculture, 254: 284-292.

Nakada, M. 2008. Capture-based aquaculture of yellowtail. In: Lovatelli and P.F. Holthus (eds.). Based aquaculture. global overview. A food and agriculture organization of the united nations. Rome. 199-215pp.

Nelson, S.G., E.P. Glenn, J. Conn, D. Moore, T. Walsh, and M. Akutagawa, 2001. Cultivation of gracilaria parvispora (Rhodophyta) in shrimp-farm effluent ditches and floating cages in Hawaii: a two phase polyculture system. Aquaculture, 193:239-248.

Neori, A. 1996. The form of N-supply (ammonia or nitrate) determines the performance of seaweed biofilters integrated with intensive fish culture. Isr. J. Aquac., 48:19- 27.

Neori, A., T. Chopin, M. Troell, A.H. Buschmann, G.P. Kraemer, and C. Halling. 2004. Integrated aquaculture: 
rationale, evolution and state of the art emphasizing seaweed biofiltration in modern mariculture. Aquaculture. 231:361-391.

Ohno, M. and K. Miyanoue. 1980. The ecology of the food alga Enteromorpha prolifera. Rep Usa Mar Biol. Stn., 2:11-17

Ohno, M. 1993. Cultivation of the green algae, monostroma and enteremorpha "Aonori". In: Ohno, M. and A.T. Critchley (eds.). Seaweed Cultivation and Marine Ranching. JICA, Kanagawa, Yokosuka, Japan. 7-15pp.

Pandey, R.S. and M. Ohno. 1985. An ecological study of cultivated Enteromorpha. Rep Usa Mar Biol Inst Kochi Univ., 7:21-31.

Patadjai, R.S. 1993. Pengaruh pupuk TSP terhadap pertumbuhan dan kualitas rumput laut Gracilaria gigas Harv. Tesis. Bogor. 83hlm.

Pérez-Mayorga, D.M., L.B. Ladah, J.A. Zertuche-González, J.J. Leichter, A.E. Filonov, and M.F. Lavín. 2011. Nitrogen uptake and growth by the opportunistic macroalga Ulva lactuca (Linnaeus) during the internal tide. $J$. Exp. Mar. Biol. Ecol., 406:108-115

Person-Le Ruyet, J., R. Galland, A. Le Roux, and H. Chartois. 1997. Chronic ammonia toxicity in juvenile turbot (Scophthalmus maximus). Aquaculture, 154:155-171.

Sahoo, D., M. Ohno, and M. Hiraoka. 2002. Laboratory, field and deep seawater culture of eucheuma-serra-a high lectin yielding red alga. Algae, 17(2):127-133.

Schumacher, J., T. Dolch, and K. Reise. 2014. Transisitons in sandflat biota since the 1930s: effects of sea-level rise, eutrophication and biological globalization in the tidal Bay Konigshafen, northern Wadden sea Helgoland Marine Research, 68:289298. doi: 10.1007/s10152-014-0389-0. Schuenhoff, A., M. Shpigel, I. Lupatsch, A. Ashkenazi, F.E. Msuya, and A. Neori. 2003. A semi-recirculating, integrated system for the culture of fish and seaweed. Aquaculture, 221:167-181.

Steel, R.G.D. and J.H. Torrie. 1993. Prinsip dan prosedur statistika: suatu pendekatan biometrik. Edisi Kedua. PT. Gramedia. Jakarta.772hlm.

Strickland, J.D.H. and T.R. Parsons. 1972. A practical handbook of seawater analysis. Fish. Res. Board Can. Canada. 328p.

Timmons, M.B., J.M. Ebeling, F.W. Wheaton, S.T. Summerfelt, and B.J. Vinci. 2002. Recirculating aquaculture systems. $2^{\text {nd }}$ ed. Cayuga Aqua Ventures. Ithaca. 769p.

Troell, M., C. Halling, A. Neori, A.H. Buschmann, T. Chopin, C. Yarish, and N. Kautsky. 2003. Integrated mariculture: asking the right questions. Aquaculture, 226:69-90.

Takeuchi, T. 1988. Laboratory work chemical evaluation of dietary nutrients. In: Watanabe, T. (ed). Fish nutrition and mariculture. Department of Aquatic Bioscience. Tokyo University of Fisheries. 179-225pp.

Van Rijn, J., Y. Tal, and H.J. Schreier. 2006. Denitrification in recirculating systems: theory and applications. Aquacultural Engineering, 34:364376.
Diterima
: 2 Juli 2016
Direview : 23 Agustus 2016
Disetujui : 2 November 2017 
